\title{
THE LAW-IN-ACTION OF THE INTERNATIONAL CRIMINAL COURT
}

\author{
By Mahnoush H. Arsanjani and W. Michael Reisman *
}

When we are dealing with words that also are a constituent act, like the Constitution of the United States, we must realize that they have called into life a being the development of which could not have been foreseen completely by the most gifted of its begetters.

\section{-Missouri v. Holland (Oliver Wendell Holmes Jr., J.)}

As the International Criminal Court (ICC) moves from an exhilarating idea to a carefully negotiated document and finally to an operational institution, the cogency of its conception will be tested by the manifold realities of international politics, not the least of which will be the practical and financial limits those realities may place upon investigation and prosecution. The drafters of the Rome Statute ${ }^{1}$ benefited from important previous experiments- the Nuremberg Tribunal and the International Criminal Tribunals for the Former Yugoslavia and for Rwanda. But once the Court is launched, the predecessors and prototypes that were so helpful in the drafting stages will be of less and less assistance. The ICC must operate in a substantially different context than the earlier efforts, and the problems it will encounter (and already is encountering) will be different from and may prove more formidable than those facing its prototypes.

Analytically, there are two types of international criminal tribunals. The first, exemplified by the tribunals at Nuremberg and Tokyo, may be called ex post tribunals, in that they are established after the acute and violent situation in which the alleged crimes occurred has been resolved by military victory or political settlement. As a result, the tribunals' operations do not affect international security concerns; even if such considerations are present, they are not likely to be of paramount importance. Hence, ex post tribunals should not have to concern themselves with the thorny questions of the legality of a criminal court's taking such considerations into account or the ethics of deciding to be oblivious to them.

The second type of tribunals may be called ex ante tribunals, in that they are established before an international security problem has been resolved or even manifested itself, or are established in the midst of the conflict in which the alleged crimes occurred. In these circumstances, other authoritative political entities are still engaged in reestablishing order and the ex ante tribunal's various options for decision may influence these political and often military actions. ${ }^{2}$ The ICC is the archetypal ex ante tribunal.

The responsibilities of ex ante tribunals may create conflicting pressures on both the tribunals and the agencies and actors responsible for resolving the security problem. The conflicting pressures may produce a stalemate. The point was made succinctly in a statement by the Catholic archdiocese's Justice and Peace Commission of Gulu in the northern Ugandan district: "To start war crimes investigations for the sake of justice at a time when the war is not yet over, risks having, in the end, neither justice nor peace delivered." 3 Thus, a formidable challenge falls on the prosecutors and eventually on the judges who must determine whether and how to set priorities among their curial responsibilities and the inevitable political consequences of their actions.

\footnotetext{
- Mahnoush H. Arsanjani is Deputy Director, Codification Division, Office of Legal Affairs, United Nations. W. Michael Reisman is a member of the Board of Editors. The authors acknowledge with gratitude the comments and suggestions of Robert Sloane. The views expressed here are personal views of the authors.

' Rome Statute of the International Criminal Court, July 17, 1998, 2187 UNTS 3, reprinted in 1 UNITED NATIONS DiPlOMATIC CONFERENCE OF PleNIPOTENTIARIES ON THE ESTABLISHMENT OF AN INTERNATIONAL CRIMINAL COURT, OFFICIAL RECORDS (1998) [hereinafter Rome Statute].

${ }^{2}$ The Rwanda Tribunal is an ex post tribunal. The Former Yugoslav Tribunal is also essentially ex post, in that by the time of its operation, there was already a general outline of a political settlement, supported by a United Nations political and a NATO military presence in the arena.

${ }^{3}$ Uganda: ICC Could Suspend Northern Investigations-Spokesman, IRIN News (Apr. 18, 2005), at <http:// www.irinnews.org $>$.
} 
The prosecutors may find it particularly difficult if they have to negotiate and reach accommodations or agreements with the agencies or actors responsible for resolving the security problem, including by abandoning an otherwise admissible action for which there were reasonable grounds to proceed.

Article 53(1)(c) of the Rome Statute ${ }^{4}$ indicates that the drafters were aware of the magnitude of the challenge these particular problems could present and, apparently, their implications for the very juridical character of the Court, as the provision requires the prosecutor, when making a decision solely on the basis of Article $53(1)(\mathrm{c})$, to inform the pretrial chamber of his or her decision. "In such a case," Article 53(3)(b) provides, "the decision of the Prosecutor shall be effective only if confirmed by the Pre-Trial Chamber." These sorts of problems are inherent in ex ante tribunals. Without statutory guidelines, their resolution may draw the prosecutor and the Court, under the guise of the "interest of justice," into political decisions, which may prove problematic for the image of a criminal court.

In the crucible of the investigation and prosecution of concrete cases, the ICC's "law-inaction," to borrow that inspired concept from Dean Pound, ${ }^{5}$ will surely prove quite different from that of its predecessors and may even prove quite different from that envisaged by its creators. Its law-in-action could be significantly shaped by recent developments and initiatives with respect to Uganda and the Democratic Republic of the Congo (DRC), some of which may not have been completely foreseen by the most gifted of the Rome Statute's begetters. ${ }^{6}$

\section{I.}

The drafters of the Rome Statute assumed that governments would be reluctant, in concrete cases, to surrender their national criminal jurisdiction to the Court. ${ }^{7}$ If any of the crimes listed in the Statute were committed in their respective territories or by any of their citizens, governments were presumed to prefer to prosecute the perpetrators themselves and, by effectively applying their police powers, demonstrate to their constituents (and their opponents) their ability to defend their citizens. In this way, they would gain credibility and political legitimacy. In democratic societies, governments that fail to show this ability are unlikely to remain in power long; in undemocratic societies, such failures are likely to embolden other aspirants to power.

Before and during the Rome negotiations, no one-neither states that were initially skeptical about the viability of an international criminal court nor states that supported it-assumed that governments would want to invite the future court to investigate and prosecute crimes that had occurred in their territory. To the contrary, it was assumed that the Court would become involved only in those states that were unwilling or refused to prosecute, staged a sham prosecution of their governmental cronies, or were simply unable to prosecute. ${ }^{8}$ There is no indication that the

\footnotetext{
${ }^{4}$ Article 53, paragraph 1 (c) of the Rome Statute, supra note 1, provides that in reaching a decision on initiating an investigation, the prosecutor shall consider whether, "[t]aking into account the gravity of the crime and the interests of victims, there are nonetheless substantial reasons to believe that an investigation would not serve the interests of justice."

${ }^{5}$ Roscoe Pound, Law in Books and Law in Action: Historical Causes of Divergence Between the Nominal and Actual Law, 44 AM. L. REV. 12 (1910).

${ }^{6}$ The Security Council's referral of the situation in Darfur to the ICC, by Resolution 1593 (March 31, 2005), occurred after this comment was completed.

${ }^{7}$ Trinidad and Tobago's initiative in reviving the idea of establishing an international criminal court in 1989 was based on the concern that fragile national courts would be unable to deal with the crime of drug trafficking. An international criminal court would insulate national courts from the power and terror that those involved in such activities could bring to bear. Trinidad and Tobago's idea was not acceptable to the great majority of states. Hence, the Rome Statute of the International Criminal Court moved in an entirely different direction. See Mahnoush H. Arsanjani, Reflections on the Jurisdiction and Trigger-Mechanism of the Intermational Criminal Court, in REFLECTIONS ON THE INTERNATIONAL CRIMINAL COURT 57, 68 n.8 (Herman von Hebel, Johan Lammers, \& Jolien Schukking eds., 1999).

${ }^{8}$ Report of the Ad Hoc Committee on the Establishment of an International Criminal Court, UN GAOR, 50th Sess., Supp. No. 22, para. 47, UN Doc. A/50/22 (1995); see also 1 Report of the Preparatory Committee on the Establishment of an International Criminal Court, UN GAOR, 5 lst Sess., Supp. No. 22, paras. 154-57, UN Doc. A/51/22 (1996).
} 
drafters ever contemplated that the Statute would include voluntary state referrals to the Court of difficult cases arising in their own territory. ${ }^{9}$ By voluntary referral we refer to situations in which the sole basis for satisfying the Court's admissibility test is the referral-whether effected formally or implicitly - by the state in which a crime or the situation subject to investigation has taken place.

It was thus the ICC and not a particular state that would decide to take up the cases, on the basis of its assessment of the unwillingness or inability of the state in which the crimes had occurred to undertake to prosecute them. Since the prosecutor's acceptance of cases in Uganda and the Congo does not seem to have been on the basis of the unwillingness of the states concerned to prosecute, the relevant questions are what the Statute means-or is to mean-when it says the inability of a state to prosecute and whether voluntary referral will henceforth trump what had heretofore been deemed to be inherent requirements for ICC admissibility.

Article 17 of the Statute, which deals with issues of admissibility, sets out, in paragraph 3, the elements to be considered for determining the "inability" of a state to prosecute:

In order to determine inability in a particular case, the Court shall consider whether, due to a total or substantial collapse or unavailability of its national judicial system, the State is unable to obtain the accused or the necessary evidence and testimony or otherwise unable to carry out its proceedings.

A finding of inability of a state to prosecute depends upon any of three disabling circumstances: (1) a total collapse of the national judicial system; (2) a substantial collapse of the national judicial system; or (3) the unavailability of the national judicial system. Note that all the elements for a determination are linked to the "national judicial system." One or more of these itemized circumstances must produce the following condition: the judicial system of the state in question is unable to obtain the accused or the necessary evidence and testimony, or is otherwise unable to carry out its proceedings. ${ }^{10}$ Note also that the drafters directed that only objective conditions

\footnotetext{
${ }^{9}$ This is apparent from the negotiating history of Article 14. Two concerns with regard to state referral emerged in the negotiations before and during the Rome Conference. One, expressed by nongovernmental organizations (NGOs), was that states would be reluctant to make referrals of situations to the Court and that the prosecutor should therefore be granted proprio motu powers to initiate investigations. The second was that states might abuse such an option by trying to send frivolous or politically motivated referrals with regard to situations in the territory of a political adversary. Suggestions were made throughout the preparatory negotiations to limit the potential for abuse.
}

One suggestion was to restrict the referral power by allowing referrals not from single States Parties but rather from groups of a specified number of States Parties. This suggestion did not attract widespread support as negotiations progressed. However, other proposals to prevent abuse were incorporated. One was to create an internal screening process to allow the Prosecutor to reject claims that were frivolous or not warranting international adjudication. Another was to require that interested States be notified and given an opportunity to effectively investigate and prosecute the crimes in question. The latter two proposals attracted considerable support and were eventually incorporated into the Statute, thereby offering safeguards against abuse and ensuring deference to legitimate national proceedings.

Philippe Kirsch \& Darryl Robinson, Referral by State Parties, in 1 THE RoME STATUTE OF THE INTERNATIONAL Criminal Court: A Commentary 619, 622-23 (Antonio Cassese, Paola Gaeta, \& John R. W. D. Jones eds., 2002) (footnote omitted).

${ }^{10} \mathrm{John}$ Holmes, the coordinator of the working group on complementarity who negotiated Article 17; states:

In the discussions, it was ultimately decided that further definition of total or partial collapse was not necessary, especially if an additional criterion existed. This additional factor was the State being unable to secure the accused or to obtain the necessary evidence and testimony. These two criteria were added to create the test for the Court in determining inability. Both criteria must be met for the Court to determine admissibility in this regard. The State must be unable to obtain an accused or key evidence and testimony, and its inability to do so must relate to the partial or total collapse of its judicial system. Some delegations were concerned that combining these two criteria could limit the Court's ability to act, for example, if the accused and some evidence were obtained but other aspects of the national proceedings were affected by the collapse. To meet these concerns, the following phrase was added to the test: "or otherwise unable to carry out its proceedings".

John T. Holmes, The Principle of Complementarity, in THE InTERnational Criminal Court: The Making OF The ROME STATUTE 41, 49 (Roy S. Lee ed., 1999) (italics added).

Holmes gives the following as examples for the third criterion (the state is unable otherwise to carry out its proceedings): "the absence of sufficient qualified personnel to effect a genuine prosecution could be a determining 
are to be considered. The provision does not include possible defects in the quality of justice of the national legal or, more specifically, judicial systems as a ground that might authorize the ICC to conclude that it could take jurisdiction. Such a formula would have required the ICC. to make qualitative judgments about the judicial systems of states parties.

While tribunals dealing with claims of denial of justice in contemporary international investment law tend at times to assess the overall system of justice in a respondent state, " neither the language of the Statute nor any extrinsic evidence from the process of its negotiation even suggests that states parties were assigning a censorial role to the ICC that would authorize it to appraise the quality of criminal justice in a state and "yank" the case to the international level if it found that it did not meet an international standard. For different reasons, the drafters were evidently not prepared to allow for the creation of ICC jurisdiction pro hac vice by voluntary relinquishment on the part of the state that had jurisdiction. In 1995, during the meetings of the Ad Hoc Committee on the Establishment of an International Criminal Court, the possibility was raised of voluntary relinquishment of jurisdiction by states in favor of the Court with respect to the crimes in the Statute. The reaction was not favorable:

This suggestion gave rise to reservations on the ground that it was not consistent with some delegations' view of the principle of complementarity. In this respect, the remark was made that the international criminal court should in no way undermine the effectiveness of national justice systems and should only be resorted to in exceptional cases. ${ }^{12}$

Indeed, during the drafting process, both the threshold and the magnitude of the contingency that would satisfy the Statute's admissibility requirement were increased. The draft Statute prepared by the Preparatory Committee had used the word "partial" to characterize the collapse of the national judicial system. At the Rome Conference, that word was replaced with "substantial" with a view to further reinforcing the primacy of the national court. Thus, the reason for the change was "to preclude the Court from assuming jurisdiction merely because an armed conflict exists in a State and the judicial system is partially affected. Even in such instances, the State may be able, through shifting resources or transferring the trial to other venues, to effect a genuine prosecution." 13 The consequences had to be related to the three circumstances that could destabilize the state's "national judicial system."

Should situations in which the national judicial systems of states become overburdened by the volume of cases for investigation and prosecution after, let us say, an internal or international armed conflict satisfy the requirement of inability of the national judicial system under Article 17 of the Statute? The legislative history clearly demonstrates that this particular scenario was not considered. The criteria for determining inability were intended to be more objective ${ }^{14}$ and were to be met only in situations of total or substantial collapse of a national judicial system or its unavailability. An overburdened national judicial system, an all-too-frequent condition even without the unwelcome introduction of the variable of internal conflict, is not a system that has partially or totally collapsed or is unavailable.

factor even if the State has the accused and the evidence." John T. Holmes, Complementarity: National Courts Versus the ICC, in 1 THE ROME STATUTE OF THE INTERNATIONAL CRIMINAL COURT, supra note 9, at 667, 678 [hereinafter Holmés, National Courts].

${ }^{11}$ See Mondev Int'l v. United States (NAFTA Ch. 11 Arb. Trib. Oct. 11, 2002), 42 ILM 85 (2003). In the context of diplomatic protection, the requirement of exhaustion of local remedies may be waived if the justice system is deemed defective. See Draft Articles on Diplomatic Protection Prepared by the International Law Commission on First Reading, Art. 16(a), (b) \& commentaries thereto, in Report of the International Law Commission on the Work of its Fifty-sixth Session, UN GAOR, 59th Sess., Supp. No. 10, at 75-79, UN Doc. A/59/10 (2004).

${ }^{12}$ Report of the Ad Hoc Committee on the Establishment of an International Criminal Court, supra note 8, para. 47 (emphasis added).

${ }^{13}$ Holmes, National Courts, supra note 10, at 677.

${ }^{14}$ See, in this regard, ICC, Office of the Prosecutor, Informal Expert Paper: The Principle of Complementarity in Practice (2003) [hereinafter Informal Expert Paper], which provides in Part $I$, paragraph 5 that "[t]he principle of objectivity (Article 54(1)) should be extended to admissibility fact-finding and analysis, so that willingness and ability are assessed in an objective, uniform and principled manner." This paper and other ICC documents cited below are available at the Court's Web site, < http://www.icc-cpi.int>. 
To be sure, the Statute should be subject to interpretation in the light of circumstances that did not exist at the time it was drafted or were not anticipated by its drafters. But one should not push this consideration too far. It is not hard to devise arguments for an expansive interpretation. For example, one could argue that the overburdening of a national judicial system could lead to its collapse, or could cause its inability to investigate or prosecute all relevant cases, and hence amount to the unavailability of the system to investigate or prosecute a certain number of cases. But the policy implications of such innovative interpretations should be carefully considered, since they could have significant impact on the future operation of the Statute and on other international legal policies.

A threshold and general question is whether extensive interpretation is appropriate for this genre of international agreement. The Statute is unique; in addition to constituting new international institutions, it is also a criminal code, embodying a highly articulated set of rules on criminal procedure. One may argue ${ }^{15}$ that, notwithstanding the strictures of Article 31 of the Vienna Convention on the Law of Treaties, ${ }^{16}$ it is appropriate, if not mandatory, to adopt a more contextual and policy-oriented hermeneutic for the interpretation of constitutive instruments. Recall Chief Justice John Marshall's injunction in McCulloch v. Maryland: "[W]e must never forget, that it is a constitution we are expounding." ${ }^{77}$ But Article 31 of the Vienna Convention instructs us in no uncertain terms that contemporary international treaty law has opted for textual interpretation for all other agreements. Article 31's codification aside, a strict interpretation appears more appropriate for criminal statutes, since innovative interpretations are perforce retroactive and may violate the legality principle, which is enshrined in the Rome Statute's Article 22, captioned "Nullum crimen sine lege."

1. A person shall not be criminally responsible under this Statute unless the conduct in question constitutes, at the time it takes place, a crime within the jurisdiction of the Court.

2 . The definition of a crime shall be strictly construed and shall not be extended by analogy. In case of ambiguity, the definition shall be interpreted in favour of the person being investigated, prosecuted or convicted.

3. This article shall not affect the characterization of any conduct as criminal under international law independently of this Statute.

Certainly, the very length of the Statute and the detail of treatment of the subject matters it covers manifest an intention by the drafters to leave as little opportunity as possible for later judicial interpretation. ${ }^{18}$

The intended limitation on interpretation is also apparent in Article 10 of the Statute, the only article that, curiously, does not have a title. ${ }^{19}$ This article, which is placed in Part 2, provides:

\footnotetext{
${ }^{15}$ W. Michael Reisman, Book Review, 81 AJIL 263, 266, 267 (1987) (reviewing ENCYCLOPEDIA OF PUBLIC INTERNATIONAL LAW, Instalment 7 (1984)).

${ }^{16}$ Opened for signature May 23, 1969, 1155 UNTS 331.

${ }^{17} 17$ U.S. 316, 407 (1819).

${ }^{18}$ See Arsanjani, supra note 7, at 58. In this regard, the Rome Statute differs from the statutes of the ICTY and the ICTR in two significant ways. The latter two statutes are comparatively brief, leaving considerable latitude for judicial elaboration through interpretation of their substantive provisions. Both of these statutes also leave the judges in control of the prescription of the rules of procedure and evidence. The drafters of the Rome Statute quite intentionally moved in the other direction. Not wishing to repeat the experience of the statutes of the two ad hoc criminal tribunals, the negotiators inserted a substantial number of provisions on procedural issues, in addition to the detailed description of crimes and provisions on jurisdiction. Indeed, they went even further, negotiating a separate agreement on the Rules of Procedure and Evidence. The purpose of all of these exercises was to leave little need for interpretation by the Court. For the Rules of Procedure and Evidence, see ASSEMBLY OF STATES PARTIES TO THE ROME STATUTE OF THE INTERNATIONAL CRIMINAL COURT, FIRST SESSION, OFFICIAL RECORDS 10-107, UN Doc. ICC-ASP/1/3, UN Sales No. E.03.V.2 (2002).

${ }^{19}$ Article 10, which was designated as Article $Y$ in the negotiations before and during the Rome Conference, was originally intended to be included as a paragraph of the article that defines the crimes under the Statute. But at the Rome Conference, once there was agreement on the definition of the crimes and the jurisdiction of the Court in separate articles, Article $Y$ was retained as a separate provision; and since the negotiations on this part of the Statute (Part 2), led by the Bureau of the Committee of the Whole, lasted until the end of the conference and bogged down over controversial questions of jurisdiction and the crime of aggression, the fact that Article $Y$, as Article 10, had no title, was overlooked.
} 
"Nothing in this Part shall be interpreted as limiting or prejudicing in any way existing or developing rules of international law for purposes other than this Statute" (emphasis added). While the article was originally intended to apply to the definitions of the crimes, it now applies to the whole of Part 2, Jurisdiction, Admissibility and Applicable Law, which contains not only the definition of the crimes but also the provisions on admissibility, including Article 17. The original purport of the article was to avoid freezing the development of international law with respect to crimes that were also defined in the Statute ${ }^{20}$ But the last phrase "for purposes other than this Statute," which was added at the Rome Conference, insulates at least Part 2 from any further development of international law; hence, it substantially narrows the latitude for interpretation. While this limitation may not exclude interpretations involving the reasonable adaptation of a particular provision to specific circumstances, it appears, in our view, to be a far cry from a general license to engage in extensive interpretation of the Statute.

As is customary for a criminal code, the drafters of the Statute attempted to use objective criteria as often as possible. Criteria for establishing the jurisdiction of the Court and the admissibility of cases were drafted with the intention of safeguarding the independence of the Court, as well as the primary jurisdictional competence of the states concerned. In the light of this object and purpose, Article 17 of the Statute on admissibility should apparently be interpreted with the restraint and prudent construction accorded to a body of criminal law, not to speak of the respect for text enshrined in Article 31 of the Vienna Convention on the Law of Treaties. As mentioned earlier, the preference of the drafters for objective standards is itself an indicator of their intention.

Whether a particular national judicial system is overburdened is a matter of judgment. Hence, the prosecutor's assessment that the judicial system of a particular state is overburdened and therefore cannot conduct the investigation or prosecution of a certain number of perpetrators of serious crimes arising under the Statute could be challenged by the state if it did not wish the matter to be referred to the Court. After all, the state has considerable control over the fact and consequences of being "overburdened," as distinct from total or partial collapse; for example, it may reallocate resources or give priority to the consideration of cases on its dockets that are related to crimes under the Court's jurisdiction.

Conversely, the voluntary referral by a state to the Court on the ground that its national judicial system is overburdened leaves the judgment on the matter to the state. Thus, a system of voluntary referral could open the way to using the Court as a backup to national judicial systems that are otherwise competent and to the selective externalization of difficult cases, relieving governments of the pressure to develop and expand their national judicial systems to process the crimes enumerated in the Statute. And precisely such national developments were a primary objective of the ICC enterprise.

A different analysis was developed in the informal expert paper prepared for the Office of the Prosecutor in 2003 by a group of distinguished jurists. ${ }^{21}$ Based on the chapeau of Article 17, the experts purport to find in the two specified contingencies in Article 17(1)(a)-unwillingness and inability - three contingencies:

17. Although it is common to emphasize the "unwilling or unable" test in Article 17, the Article in fact deals with three logically distinct circumstances.

18. First, the most straightforward scenario is where no State has initiated any investigation (the inaction scenario). In such a scenario, none of the alternatives of Arts. 17(1)(a)-(c) are satisfied and there is no impediment to admissibility. Thus, there is no need to examine

${ }^{20}$ See also Article 10, in COMMENTARY ON THE ROME STATUTE OF THE INTERNATIONAL CRIMINAL COURT 31521 (Otto Triffterer ed., 1999); Mohamed Bennouna, The Statute's Rules on Crimes and Existing or Developing International Law, in 2 THE ROME STATUTE OF THE INTERNATIONAL CRIMINAL COURT, supra note 9, at 1101 .

${ }^{21}$ Informal Expert Paper, supra note 14. The terms of reference of the paper list the participants but state that "the Group operated in a collegial manner to try to develop a collective report, and hence the views reflected in this document do not necessarily reflect the views of each individual member." Id. at 2. 
the factors of unwillingness or inability; the case is simply admissible under the clear terms of Article 17. ${ }^{22}$

Earlier, we concluded that the Statute excluded voluntary referrals as a basis for admissibility of a case. But does not the experts' interpretation create a form of voluntary referral by allowing a state to do nothing about certain cases in the expectation that the prosecutor will take them? If glossators say that henceforth mere inaction will authorize the ICC to proceed, states are on notice that they can achieve the effect of voluntary referral simply by abstaining from action. As the experts put it, "the case is simply admissible under the clear terms of Article 17."

The glossators' notice to states is hardly subtle. In a section of their report entitled "Uncontested admissibility and consensual sharing of labour," 23 the experts state: "There may also be situations where the appropriate course of action is for a State concerned not to exercise jurisdiction, in order to facilitate admissibility before the ICC. ${ }^{24}$ Even the procedure is made explicit:

Acknowledgement of non-exercise of jurisdiction: In these types of situations, it may be appropriate for the State concerned to simplify the admissibility proceedings by expressly acknowledging that it is not investigating or prosecuting particular cases, in favour of ICC jurisdiction. This does not entail any re-writing or alteration of the jurisdictional and admissibility regime of the Statute. ${ }^{25}$

This last assurance is not entirely persuasive.

The ICC prosecutor seems to follow the approach of the expert group to Article 17 of the Statute. In a policy paper issued in September 2003, the prosecutor sets out guidelines for.his office. After stating that the Court has limited resources, he describes a two-tiered approach that his office will employ:

On the one hand [the Office of the Prosecutor] will initiate prosecutions of the leaders who bear most responsibility for the crimes. On the other hand it will encourage national prosecutions, where possible, for the lower-ranking perpetrators, or work with the international community to ensure that the offenders are brought to justice by some other means. ${ }^{26}$

Later in the policy paper, the prosecutor elaborates his vision of the two-tiered approach, speaking of the division of labor between the Court and national judicial systems as the "most logical and effective approach":

There may be cases where inaction by States is the appropriate course of action. For example, the Court and a territorial State incapacitated by mass crimes may agree that a consensual division of labour is the most logical and effective approach. Groups bitterly divided by conflict may oppose prosecutions at each others' hands and yet agree to a prosecution by a Court perceived as neutral and impartial. There may also be cases where a third State has extraterritorial jurisdiction, but all interested parties agree that the Court has developed superior evidence and expertise relating to that situation, making the Court the more effective forum. In such cases there will be no question of "unwillingness" or "inability" under article 17.

Thus, the law-in-action of Article 17 appears to be evolving in significant ways.

II.

Uganda, a state party to the Rome Statute, made the first voluntary referral of a situation to the ICC in December 2003. The situation in question involves crimes committed in the course of the internal armed conflict in northern Uganda, which has continued for the last eighteen

${ }^{22} I d .$, pt. III(a)(1), paras. 17-18.

${ }^{23} I d$., pt. IV(a), paras. $59-66$.

${ }^{24}$ Id., para. 61 .

${ }^{25}$ Id., para. 62.

${ }^{26}$ ICC, Office of the Prosecutor, Paper on Some Policy Issues Before the Office of the Prosecutor, pt. I, at 3 (Sept. 2003).

${ }^{27} I d$., pt. II(1.1), at 5 (emphasis added). 
years with a frightful toll of massacres, rapes, child abuse, and other grievous human rights violations. One of the results of the conflict is approximately 1.5 million internally displaced persons. ${ }^{28}$ On July 29, 2004, the prosecutor announced that he had determined that there was a reasonable basis to commence an investigation into crimes allegedly committed in northern Uganda. $^{29}$

While some may welcome the Ugandan initiative as a sign of confidence and trust in the ICC, that enthusiasm should be tempered for three reasons. First, the move could encourage governments to externalize to the Court the domestic political problems they are unable or unwilling-because they do not wish to invest the necessary resources-to manage or resolve. Second, it permits the referring government to co-opt the ICC in a confrontational criminal context for what-despite all the attendant violence-may essentially be political struggles, for which negotiation and settlement might be the only practicable mode of restoring minimum order. Third, such a referral does not seem to meet the requirement of admissibility under Article 17 of the Statute. ${ }^{30}$

The events in northern Uganda are part of a long-running conflict between the government and the Lord's Resistance Army (LRA) rebels. The aims of the latter are obscure, but they include the ousting and replacement of the current government of Uganda. Ethnically, LRA members belong to the Acholi tribes, but their victims are Acholis as well. Among other crimes attributed to the rebels are indiscriminate killing and abducting children, whom they force to fight as soldiers and serve as sex slaves. Disobedience is not tolerated, leaving the children no choice but to stay and fight with the rebels.

For years, the rebels maintained their camps in southern Sudan, from where they operated in northern Uganda. In early March 2004, Sudan and Uganda signed a military protocol ${ }^{31}$ allowing for operations by the Ugandan military against LRA positions and camps.

In 2000 the Ugandan government adopted an amnesty law granting immunity from prosecution to LRA members who would voluntarily surrender ${ }^{32}$ An amnesty commission was established with the aim of resettling rebels who surrendered. The World Bank sponsored the MultiDonor Resettlement Project to provide financial assistance for the resettlement of rebels. A peace opening was also launched by the Acholi Religious Leaders Peace Initiative, which advocates resolution of the conflict in the north through negotiation and communication with the rebels.

A relocation project, by its nature, requires an ongoing commitment by the Ugandan government and, in particular, the allocation of sufficient resources to implement it. In 2002, however, Uganda passed the Anti-Terrorism Act, which undermines the Amnesty Act. ${ }^{33}$

\footnotetext{
${ }^{28}$ Uganda submitted its instrument of ratification to the Rome Statute on June 14, 2002. In accordance with its Article 126, the Statute entered into force for Uganda on September 1, 2002, the first day of the month after the sixtieth day following the deposit of the instrument of ratification. The situation in northern Uganda in relation to crimes committed on and after September 1, 2002, thus falls within the temporal jurisdiction of the Court.

${ }^{29}$ ICC Press Release, Prosecutor of the International Criminal Court Opens an Investigation into Northern Uganda (July 29, 2004).

${ }^{30}$ The prosecutorial initiatives are subject to review and challenge under Articles 18 and 19 of the Statute. See infra Pp. 396-97.

31 UNITED NATIONS CONSOlIDATED APPEALS PROCESS, UgANDA: MID-YEAR Review 2004, at 3 (copies can be obtained from the UN Office for the Coordination of Humanitarian Affairs, CAP@reliefweb.int).

${ }^{32}$ Uganda Amnesty Act, 2000, available at <http://www.c-r.org/accord/Uganda/accord l l/keytext.shtml\#7>.

${ }^{33}$ Anti-Terrorism Laws Undermine Amnesty Act of 2000, in NORWEGIAN REFUGEE COUNCIL, GLOBAL. IDP PROJECT, PROFILE OF INTERNAL DISPLACEMENT: UGANDA 48 (July 7, 2004), available at <http://www.db.idpproject.org/ Sites/idpSurvey.nsf/wCountries/Uganda $>$. The government has also indicated that it would amend the Amnesty Act to exclude the commander of the LRA. See New Amnesty Law to Exclude Top LRA Leaders, IRIN News (Dec. 17, 2003), at < http://www.irinnews.org>; Acholi Religious Leaders Against Amendment to Amnesty Law (Feb. 12, 2004), at <http://parliament.go.ug/details.php?newsld = 350>; see also Whose Justice? Perceptions of Uganda's Amnesty Act 2000: The Potential for Conflict Resolution and Long-Term Reconciliation (Refugee Law Project, Makerere University, Kampala, Working Paper No. 15, Feb. 2005), available at < http://www.refugeelawproject. org $>$ (suggesting that despite challenges to its implementation, the amnesty law in general has been perceived as a vital tool for conflict resolution in northern Uganda).

For the major features of the Anti-Terrorism Act, see S. B. Bossa \& Titus Mulindwa, The Anti-Terrorism Act, 2002 (Uganda): Human Rights Concerns and Implications, Paper presented to the International Commission of Jurists (Sept. 15, 2004), available at <http://www.icj.org/IMG/pdf/Paper_Bossa.pdf>
} 
In the meanwhile, the situation in the area of conflict has been deteriorating. Humanitarian and aid workers have had difficulty gaining access to affected areas and the refugee camps. In the camps, the government has been unable to provide security and has relied primarily on "local defense" units such as the "Arrow Boys" of Teso and the "Rhinos" of Lira. The members of these groups are armed by the government's security forces but reportedly function essentially as uncontrolled militias. Not surprisingly, this arrangement has not succeeded in appreciably improving security but, rather, has spawned problems of its own. ${ }^{34}$

The provision of humanitarian aid for vital health needs, water, and sanitation requires an on-the-ground presence for a sustained period of time. In the absence of government security, aid workers, if they are to conduct their humanitarian operations, have no choice but to negotiate with the rebels in the hope of reaching some understanding about access and operations.

In sum, the Ugandan government had been unable to resolve the problem in the north for at least eighteen years. Whatever the reason for this failure and however hideous the crimes committed, one wonders what contribution to the settlement of the dispute accrues from transferring the problem, at this juncture, to the International Criminal Court, a body that was neither intended nor equipped to resolve, through judicial means, a longstanding political problem of a government. ${ }^{35}$ As a practical operational matter, Uganda's referral of a situation involving

${ }^{34}$ A coalition of nongovernmental organizations (Civil Society Organizations for Peace in Northern Uganda) said in a report regarding the situation in northern Uganda, as quoted by IRIN News:

The war in the region is a dirty war-a war in which civilians have become the principal strategic targets and victims of violence; in which civilians have become the field upon which the conflict is fought, and through which victory is being sought ....

A serious protection vacuum exists in the region. . . Gross abuses of international humanitarian and human rights law are perpetrated against civilians on a grand scale, with culpability on both sides.

The government has so far failed in its obligation to mobilise a fully effective strategy for humanitarian protection in northern Uganda .... These [military] strategies have in fact contributed to the production of the humanitarian protection crisis, [because] the military offensive has not proven itself successful in adequately protecting civilians from abuses by the LRA.

This process has flooded the region with small arms, creating local armies with no formal accountability, that themselves prey on the vulnerable, and are exploited by the powerful.

Seventy percent of IDPs [internally displaced persons] claim that lack of food and hunger are the most serious threats that they face, and malnutrition rates continue to be of concern while lack of access to fuel wood was a key concern ....

The report was launched on December 10,2004, in the northern town of Gulu. Uganda: Northern Conflict Creates Protection Crisis-NGOs, IRIN News (Dec. 14, 2004), at <http:// www.irinnews.org>; see also Behind the Violence: Causes, Consequences and the Search for Solutions to the War in Northern Uganda (Refugee Law Project, Makerere University, Kampala, Working Paper No. 11, Feb. 2004), available at < http://www.refugeelawproject. org $>$ (reviewing the reasons for violence in northern Uganda and making a series of recommendations, notably against a military solution).

${ }^{35}$ See Refugee Law Project (Faculty of Law, Makerere University), Position Paper on the announcement of formal investigations of LRA by the ICC (July 28, 2004), available at <http:/www.refugeelawproject.org >. This paper criticizes the referral to the ICC and the acceptance by the ICC prosecutor of the referral, noting that the latter "raises a number of practical and legal issues, which the drafters and supporters of the Rome Statute never envisaged and which undermine the legitimacy of the ICC at the grassroots level," in particular "the disjuncture between international conceptions of justice and local community traditions, values, and notions of justice." Id. at 1 . The paper poses several pertinent questions:

- Can an investigation by the ICC help bring an end to an ongoing conflict?

- Is the Prosecutor informed of the political context in which the referral was made in December by the Government of Uganda? And does the political context matter?

- Should the Prosecutor have taken into consideration the interests of those affected by the war before going public? Is he aware of those interests?

- What are the likely consequences of the Prosecutor's announcement on the victims?

- Can those affected by the ongoing war challenge his decision?

- What power and procedural guidelines does the Statute establishing the ICC give the Prosecutor in dealing with situations as complex as the war in northern Uganda? 
indictments of rebels who may themselves be critical to access for investigation, the collection of evidence, the interrogation of witnesses, and the arrest of accused individuals amounts to washing its own hands of an insoluble internal problem while transferring a prescription for failure to the Court. ${ }^{36}$

The selectivity of the referral raises still another justice problem. Atrocities have allegedly been committed by the Ugandan army. The president of Uganda has been quoted as saying-not unambiguously - that he is prepared to cooperate with the prosecutor with regard to these allegations: "I am ready to be investigated for war crimes ... and if any of our people were involved in any crimes, we will give him up to be tried by the ICC." "And in any case, if such cases are brought to our attention, we will try them ourselves." 37

This situation is acutely problematic for the ICC, for two reasons: In an internal military struggle where the referring government is one of the parties, it is referring its adversaries to the ICC while apparently retaining jurisdiction over its own putative perpetrators against whom there may also be serious allegations that sound in the Statute. At the same time, the statement acknowledges that the national judicial system of Uganda is operational, as the president seems to plan to have Iocal courts conduct trials of any accused governmental military or civilian official.

Given that the LRA is continuing to commit atrocities, the urgent goal would seem to be to end the conflict, either militarily or by negotiation. ${ }^{38}$ If neither of these strategies has proven

- If the Prosecutor goes ahead to institute the investigations as planned, what are the consequences on those living in the war zone, especially potential witnesses?

- How will the ICC protect victims and witnesses in northern Uganda while the perpetrators are still [at] large? Particularly considering that the State itself has failed to guarantee the security of its citizens?

- Will the Ugandan People's Defense Force (UPDF) be investigated as well? If so, what cooperation will the Prosecutor's Office get from the Government?

Id. at $1-2$.

The prosecutor's initiative in northern Uganda has been characterized as "distuptive" to the peace process because "it discourage[s] LRA members from seeking amnesty pursuant to a Ugandan law passed in 2000-with vigorous support from the Acholi community" and "potentially undermines traditional mechanisms of reconciliation and reintegration. The threat of prosecution may serve as a stick, but the carrot of amnesty and reconciliation must be retained in order to reinforce the peace process." Katherine Southwick, North Ugandan Conflict, Forgotten but Still Deadly, YALEGLOBAL (Mar. 9, 2005), at <http://yaleglobal.yale.edu>.

${ }_{36}$ Perpetrators of crimes, victims, or witnesses may take refuge in other states, which, if parties to the Rome Statute, are obliged to cooperate with the Court under Part 9 of the Statute. But the obligation is contingent on various legal and political factors. In the absence of an indictment or in case of challenges to admissibility and jurisdiction, the obligation of cooperation of a state party could be limited. Under Article 95 of the Statute, if admissibility is challenged under Articles 18 and 19 , a state may postpone the execution of a request for cooperation pending a determination by the Court, unless the Court has specifically decided that the prosecutor may pursue the collection of evidence. In some situations, subregional, regional, or tribal politics may dispose some actors against cooperation, despite the fact that the field of investigation requires their cooperation. The Statute does not appear to provide effective means of enforcement. While a state's noncooperation may be raised at the Assembly of States Parties to the Rome Statute, the Assembly can do little in terms of sanctions or enforcement.

${ }^{37}$ Remarks by ICC Prosecutor Luis Moreno-Ocampo, 27th Meeting of the Committee of Legal Advisors on Public International Law, Strasbourg (Mar. 18, 2004) (quoting President Museveni of Uganda (emphasis added) (ellipsis in original)), at <http://www.iccnow.org/documents/statements/others/ICCProsecutorCADHI18Mar04.pdf>.

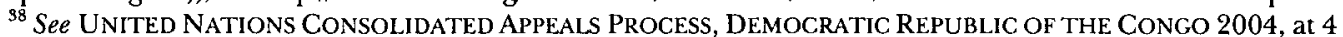
(copies can be obtained as for the report supra note 31 ). See also the statement by the spokesman for the secretarygeneral on April 16, 2004, regarding dialogue between the Ugandan government and the rebels in the north:

The Secretary-General welcomes the announcement made on 14 April [2004] by President Yoweri Museveni of Uganda, in which he reiterated his readiness to talk with the leaders of the Lord's Resistance Army (LRA), either directly or through intermediaries, in order to reach a peaceful resolution of the conflict in northern Uganda.

UN Press Release SG/SM/9258, AFR/901 (Apr. 16, 2004).

The European Union's commissioner for development and humanitarian aid, Luis Michel, said on December 16,2004 , that flexibility and mutual understanding between the Ugandan government and the LRA were essential in the effort to end the longstanding conflict in northern Uganda. Uganda: EU Official Urges Flexibility in Effort to End Conflict, IRIN News (Dec. 17, 2004), at <http://www.irinnews.org > Jan Egeland, the United Nations under-secretary-general for humanitarian affairs, commended Ugandan government efforts to end, through dialogue, the conflict with the LRA in northern Uganda. Uganda: Historic Opportunity for Northern Peace ProcessUN, IRIN News (Dec. 8, 2004), at <http://www.irinnews.org > Jean-Marc de la Sablière, French ambassador to the United Nations, in the context of the meeting of the Security Council with President Museveni of Uganda on November 26, 2004, is reported to have told the press that "our message to Uganda was that the humanitarian crisis in the north should be settled as soon as possible" and that "[ $t$ ] he president [Museveni] told us that there 
effective, what will referral of the situation to the ICC accomplish? And, again, how can the ICC even act? The prosecutor himself has recognized the formidable aspects of pursuing investigation and arrest in northern Uganda. He said:

The situation presents a number of difficult considerations. For example, we are talking with local groups to discuss their concerns about the role of international justice.

We will face extreme challenges in attempting to investigate in a war zone. Ensuring the safety and security of my investigation teams is a fundamental priority. We are working to obtain immunity agreements.

The issue of how to carry out arrests is another major consideration. The government of Uganda has faced great difficulties carrying out arrests, so we are exploring other possibilities. ${ }^{39}$

For the managers and custodians of the ICC, the urgent policy question is whether the ICC should be used by governments to resolve their internal political problems. While the political situation in Uganda is still evolving, the essential issues that affect the Rome Statute are clear. ${ }^{40}$ Nor is Uganda the only country in which rebels control part of the national territory and commit crimes that could fall within the jurisdiction of the ICC. What will the ICC do if, following the Ugandan precedent, more of the governments of these states try to refer these situations to the Court so as to deflect internal or international criticism for their unresolved political problems? The failure of governments will simply become the failure of the ICC, for, having assumed the responsibility a government has shifted to it, the Court will find that it is unable to conduct any serious investigation and prosecution.

In addition, if governments can use the ICC for their own political ends, can they (or successor governments) later withdraw their referrals should they come to believe that it could serve their purposes? ${ }^{41}$ Certainly, under the construction proposed by the experts, in which admissibility is to be inferred from inaction, a later indication of willingness to undertake action could complicate the prosecutor's initiative. And is there anything in the Statute to prevent a state from withdrawing the referral, especially before trial has commenced?

In strict legal terms, a voluntary referral such as the one by Uganda appears to fail to satisfy the threshold for admissibility set out in Article 17 of the Statute. There is no evidence that a "total or substantial" collapse of the "national judicial system" of Uganda has occurred or that its "national judicial system" is "unavailable." Even Uganda has not made that claim. In point of fact, the insecurity in the north has not affected the national judicial system of Uganda. The inability of the government to capture the accused or to conduct investigations in the north is not "due" to any problems of the national judicial system. An ineffective police force in the northern region does not meet the requirement set out in Article 17 of the Statute.

were good prospects for peace in Uganda." He said that "[a]ll the international community and the Council are concerned with ... what is taking place in northern Uganda," adding that "[w]e are concerned about the situation of child soldiers-it is not only to condemn the situation, but we need to find a solution." Security Council Urges Museveni to End Conflict in North, IRIN News (Nov. 26, 2004), at <http://www.irinnews.org>.

${ }^{39}$ Remarks by ICC Prosecutor Luis Moreno-Ocampo, supra note 37 (emphasis added).

${ }^{40}$ The government of Uganda and the LRA have been holding on-and-off peace talks. On April 16, 2005, the Office of the Prosecutor held meetings with members of the Ugandan Parliament and leaders of the Acholi, Iteso, Lango, and Madi communities of northern Uganda. Thereafter, Yves Sorokobi, an ICC spokesman, stated, "If it is in the interest of justice to proceed with a peace agreement, the ICC is ready to suspend its investigation." The same report states that "Moreno-Ocampo was reported by international media as saying if a solution to end the violence was found, and continuing the investigation did not serve the interests of justice, then the ICC would stop the probe." Uganda: ICC Could Suspend Northern Investigations--Spokesman, supra note 3. For the joint statement, see ICC Press Release, Joint Statement by ICC Chief Prosecutor and the Visiting Delegation of Lango, Acholi, Iteso and Madi Community Leaders from Northern Uganda (Apr. 16, 2005), at <http://www.icc-cpi.int>.

${ }^{41}$ In the context of the International Court of Justice, prior to oral hearing the parties may request that the Court delay hearings. The Democratic Republic of the Congo submitted a claim, in 1999, to the ICJ against Uganda, accusing it of armed intervention in the Congo. Three days before oral hearings, in November 2003 , the Congo requested that the Court delay the hearing to enable diplomatic negotiations in which the parties were engaged to be conducted in an atmosphere of calm. Uganda informed the Court that it supported the proposal. The Court, while regretting the "unexpected situation," agreed to the postponement of the oral hearing. ICJ Press Release 2003/39 (Nov. 7, 2003). 
The innovative interpretation of Article 17 may produce even stranger results. Under Article 19 of the Statute, a referral is subject to challenge, by both the accused and the state with jurisdiction over the case, which, bizarrely, includes the state that made the voluntary referral, an eventuality we will consider below. Article 19 on admissibility and challenge to the jurisdiction of the Court was drafted on the assumption that a state would be reluctant to have one of "its" cases come to the Court, so that it had to be given an opportunity to challenge jurisdiction, whether triggered by the proprio motu power of the prosecutor or by a referral by another state with possibly ulterior political motives. No provision in the Statute permits an estoppel that would preclude a state that made a referral to the Court from then challenging the Court's jurisdiction under Article 19.

Article 19, paragraph 1 of the Statute requires the Court to satisfy itself that it has jurisdiction over a case before it. As regards admissibility, paragraph 1 gives the Court an option. It provides that the Court "may, on its own motion, determine the admissibility of a case in accordance with article 17." ${ }^{22}$ In determining its jurisdiction, the Court must satisfy itself that the principle of complementarity, one of the three important underlying principles of the Statute, ${ }^{43}$ has been respected: that the Court may assume jurisdiction only when national jurisdictions are unwilling or unable to exercise it.

Article 1 of the Statute provides that the Court "shall be complementary to national criminal jurisdictions." Article 17 elaborates on the notion of complementarity in the context of the admissibility of a case. The Court has not yet had a case before it for trial, but it is assumed that, like the International Court of Justice or any other international court or tribunal, it will deal with the issues of jurisdiction and admissibility before plunging into the substance of the case. Given the apparent willingness of the Office of the Prosecutor to look into the situation of northern Uganda, we will have to wait and see how, in the light of the complementarity principle of Article 17, the Court will treat a voluntary referral-however it is effected-by a state with jurisdiction whose national judicial system has not collapsed totally or. partially.

Even if the Court itself is disinclined to raise the issue of complementarity and admissibility sua sponte, that is not necessarily the end of the matter. Paragraph 2 of Article 19 allows for a challenge to the "jurisdiction" of the Court and the "admissibility" of a case by three classes of actors: (a) an accused; (b) a state that has jurisdiction over the case; and (c) any other state whose consent to the jurisdiction of the Court is required under Article 12. For the purposes of this paper, we will deal with the first two classes whose members enjoy standing to challenge the Court's jurisdiction or the admissibility of a case that has been voluntarily referred: the accused and the state with jurisdiction over the case. In the context of the material treated in this comment, the latter is the state that purports to make the voluntary referral.

An accused or a person for whom a warrant of arrest or a summons to appear before the Court has been issued has the right to question the jurisdiction of the Court and could challenge whether the requirements of admissibility of Article 17 have been satisfied. The Court would seemingly find it difficult to take the state's voluntary referral as per se fulfilling the requirements of Article 17, for paragraph 3 of Article 17 sets out objective criteria-"a total or substantial collapse or unavailability of its national judicial system"- that must be established. These are factual questions. ${ }^{44}$ The provision does not mention or imply voluntary referral effected by inaction that was not caused by the unwillingness or unavailability of the national judicial system. Those specified criteria are the only ones that may meet Article 17's requirements. If that were not so, a state's consent, expressed in the act of referral, would automatically override the statutory right that was granted to the accused and any other state that might have jurisdiction

\footnotetext{
${ }^{42}$ Rome Ștatute, supra note 1 , Art. 19(1) (emphasis added).

${ }^{43}$ Three principles underlie the Statute. The first is the principle of complementarity. The second is that the Statute is designed to deal only with the most serious crimes of concern to the international community as a whole. The third is that the Statute should, to the extent possible, remain within the realm of customary international law. Mahnoush H. Arsanjani, The Rome Statute of the International Criminal Court, 93 AJIL 22, 24-25 (1999).

${ }^{44}$ Holmes, National Courts, supra note 10 , at 678 .
} 
over the case to challenge its admissibility and the Court's jurisdiction. Thus, it is all the more puzzling to read how the aforementioned group of experts deals with the rights of the accused in their gloss on Article 17:

Rights of the Accused: For greater clarity, it may be reiterated that such arrangements do not purport to remove the procedural right of the accused to raise challenges to admissibility. However, in the clear absence of any investigation or prosecution by a State, an admissibility challenge on the grounds of complementarity would not have any merit. ${ }^{45}$

One wonders what rights are left to the accused under Article 17.

A state that has referred a situation to the Court is also entitled to challenge the Court's jurisdiction and the admissibility of the case under Article 19. Considering the pressure for resolving disputes through negotiation and the recognition that some of these disputes are not susceptible to military solutions, is it not likely that some states that have made voluntary referrals may later agree, as part of the negotiating process with their adversaries, to withdraw their referral to the ICC? Grounds for withdrawal-if grounds are needed-could be that the state has decided to use its national judicial system to deal with crimes that may have been committed in a particular situation. A withdrawal of a voluntary referral could be made anytime before the trial or at its commencement. By that time, the Office of the Prosecutor would have invested substantial resources, both human and financial, over months if not years, in preparing the case for trial. A withdrawal in these circumstances would incur a considerable loss of credibility for the Court and would also represent a defeat for the policy against impunity, the principle that animates the very idea of the Court. While arguments of estoppel may be raised, the tension between the pursuit of criminal justice and the reestablishment of minimum order, which we described at the outset of this comment, would be acute.

The longer-term consequences of the innovative allowance of voluntary referral in future cases may take the ICC into areas where the drafters of the Rome Statute had not wished to tread. This development in the law-in-action could prove problematic.

III.

The Democratic Republic of the Congo has been plagued bydiolent and widespread civil war since 1999. The reports of mass killings, rapes, cannibalism, and other gross violations of human rights have been depressingly credible. It is estimated that, overall, since 1999 more than 3.4 million people have become displaced in the DRC. ${ }^{46}$ The situation in Ituri, which has a population of 4.6 million and is situated on the DRC's northeastern border with Uganda, has been singled out as a humanitarian catastrophe. ${ }^{47}$ The UN Office for the Coordination of Humanitarian Affairs estimates that between five hundred thousand and six hundred thousand internally displaced persons inhabit this region alone, many of whom are in hiding. ${ }^{48}$ The death toll has been estimated at more than sixty thousand, and countless additional victims have been maimed or mutilated. ${ }^{49}$ Reports indicate that atrocities have been committed by all sides in the various conflicts, including by those operating under the direct control of neighboring states. ${ }^{50}$

The seven-year civil war has led to the collapse of the internal structure of government. The national judicial system is reportedly in such disarray that it could take years to establish a functioning judiciary. Even with massive outside help and even if it proves possible to settle the civil

${ }^{45}$ Informal Expert Paper, supra note 14, pt. IV(a), para. 64.

${ }^{46}$ UNITED NATIONS CONSOLIDATED APPEALS PROCESS, supra note 38, at 18.

${ }^{47}$ Second Special Report of the Secretary-General on the United Nations Organization Mission in the Democratic Republic of the Congo, UN Doc. S/2003/566, at 3, para. 10 [hereinafter Second Special Report].

${ }^{48} I d$.

${ }^{49} I d$.

${ }^{50}$ ITURI: "Covered in BloOd," 15 Human Rights WATCh, Democratic RePUblic of CONGO, NO. 11(A), July 2003, chs. 3, 5; see also Second Special Report, supra note 47, at 3, paras. 11-12. 
war, the national judicial system of the DRC will probably be unable to investigate and prosecute the gravest crimes that have occurred in the course of the last seven years.

Atrocities continued to be committed in Ituri after July 1, 2002, the moment when the Rome Statute entered into force. That date also marked the commencement of the application of the Statute to the DRC, which had deposited its instrument of ratification on April 11,2002, as one of the initial states parties. In 2003 the Office of the Prosecutor announced that it had selected the situation in Ituri as the most urgent situation for investigation. ${ }^{51}$ Following the initiative of the prosecutor, the government of President Joseph Kabila, in April 2004, referred the entire territory of the DRC to the Court as regards events occurring after July 1, 2002. This voluntary referral, vastly expanding the ICC's geographical scope of jurisdiction, was explained by the DRC government as an effort to facilitate the prosecutor's task. ${ }^{52}$ On June 21,2004 , the prosecutor announced that he had determined that there was a reasonable basis to commence an investigation into crimes allegedly committed in the Democratic Republic of the Congo. On October 6, 2004, the ICC and the DRC signed an agreement regarding the protection of investigators and their access to the governmental archives. ${ }^{53}$

The international outcry over the grave crimes in Ituri and the general recognition of the lack of any national judicial system and any reasonable prospect for reviving or establishing such a system within a reasonable time plainly put pressure on the prosecutor to act. Moreover, the situation clearly met the requirements of Article 17, paragraph 3 of the Statute concerning the genuine inability of the state to carry out the investigation or prosecution. Hence, the legal problems precipitated by Uganda's voluntary referral, considered earlier, do not arise here. But the practical and political problems facing the prosecutor in attempting any investigation in the DRC are daunting, to say the least. They include an ongoing multiparty conflict with a sevenyear history; allegations of abuses by all parties; and ongoing international efforts to secure national reconciliation, which perforce involve all sides to the conflict. The matter is also before the Security Council.

The Security Council has not exercised the option granted to it in Article 16 of the Statute: ${ }^{54}$ to request a deferral of investigation or prosecution with respect to the situation in Ituri. As a practical matter, such a request may not be necessary at this stage; the state of chaos and insecurity and the prevalence of land mines in Ituri force a de facto deferral. It is difficult, if not impossible, for the Office of the Prosecutor to conduct any meaningful investigation on the ground or to have access to any accused. The assistance of the DRC government may be promised, but its ineffectiveness is the predicate of the referral. The prosecutor's office, in an agreement with the DRC government, has agreed to limit its investigation and prosecution to "the leaders who bear the greatest responsibility," leaving the task of dealing with other individuals to the DRC or other mechanisms:

We [the Office of the Prosecutor] have proposed a consensual division of labour with the DRC. We would contribute by prosecuting the leaders who bear the greatest responsibility. National authorities, with the assistance of the international community, could implement appropriate mechanisms to address other responsible individuals. The DRC has responded with a letter affirming that such a division of labour would be welcome. ${ }^{55}$

${ }^{51}$ ICC Press Release No. pids.009.2003-EN, Communications Received by the Office of the Prosecutor of the ICC (July 16, 2003).

${ }^{52}$ Statement of the delegate of the Democratic Republic of the Congo in the Sixth Committee, UN Doc. A/59/C.6/SR.6, para. 14 (2004) [hereinafter Statement of DRC delegate].

${ }^{53} I d$.

${ }^{54}$ Article 16 of the Rome Statute, supra note 1, provides:

$$
\text { Deferral of investigation or prosecution }
$$

No investigation or prosecution may be commenced or proceeded with under this Statute for a period of 12 months after the Security Council, in a resolution adopted under Chapter VII of the Charter of the United Nations, has requested the Court to that effect; that request may be renewed by the Council under the same conditions.

${ }^{55}$ Remarks by ICC Prosecutor Luis Moreno-Ocampo, supra note 37. 
Even though both the International Law Commission and the pre-Rome negotiations considered suggestions to limit the competence of the Court to the leaders of those responsible for such crimes, the Rome Conference decided otherwise. The negotiators reasoned that the crimes listed in the Statute are so grave that their prosecution cannot be limited to a handful at the top; no one who has committed such crimes should escape prosecution and, if appropriate, punishment. But the implication of the DRC-ICC agreement (in the context of the Congo) suggests an evolution in approach. Consider: The involvement of the ICC in the DRC is justified on the ground of inability or, as some reports indicate, the nonexistence of the DRC's national judicial system. How can other individuals below the civilian or military leadership who are accused of such grave crimes be investigated or prosecuted within a reasonable period of time, if the ICC, having taken jurisdiction because of the collapse of the national judicial system, does not pursue the matter itself? The policy of the Statute notwithstanding, the imperatives of practicality and resource limitations confront prosecutor and Court in this initiative. Under the guise of an ostensible allocation of competence or setting priorities among cases, has the focus of the ICC retracted to the leaders, extending henceforth, if at all, only episodically or opportunistically to the rank-and-file? ? $^{56}$

IV.

The $D R C$ case presents still another dilemma. In spite of the efforts made by the drafters of the Rome Statute to maintain a distance between the Court and the Security Council as a demonstration of the independence and impartiality of the Court, it is becoming increasingly apparent that, in practice, the consent and cooperation of the Security Council will be important, if not indispensable, when the Court, like any ex ante tribunal, undertakes to conduct investigations and apprehend suspects in an ongoing conflict. As a general matter, any conflict in which atrocities reach a level that requires action by the Court is likely also to involve the Security Council. Where access by humanitarian aid workers requires security forces, whether provided by the United Nations, multinational forces, or some regional arrangements, investigators of the Office of the Prosecutor, in practice, will not gain access to these areas to conduct investigations and collect evidence without the agreement and support of those security forces.

Because the Court does not have a police force, it must rely on the cooperation of states. Lawful assistance by states parties is limited to the area where they exercise jurisdiction or control. It does not extend, even if a state wished, to the emplacement of its police or security force in the territory of another state without that state's consent-or without the authorization of the Security Council. Situations of tense, ongoing internal conflict where the central government of a state is in disarray, or is a party to the conflict, or appears implicated in crimes sounding in the Statute are precisely the situations that are likely to draw in the Security Council and involve UN or UN-authorized forces on the ground. And in these situations, the only impartial police or security force that can be provided to assist the prosecutor's investigators will be UN forces, a multinational force, or forces provided by regional organizations. If UN missions are to extend such assistance to the Office of the Prosecutor, the mandates for those missions, which are drafted by the Security Council, will have to specify those tasks.

A Security Council resolution mandating UN forces may contain language that can be interpreted as allowing for an exchange of information with the prosecutor in the area of UN operations,

\footnotetext{
${ }^{56}$ Article 53, paragraph l(c) of the Statute accords considerable latitude to the prosecutor in a decision as to whether to initiate an investigation. As noted above, it provides that in deciding whether to initiate an investigation, the prosecutor shall consider whether, "[t]aking into account the gravity of the crime and the interests of victims, there are nonetheless substantial reasons to believe that an investigation would not serve the interests of justice." This provision, which was intended to cover situations of national amnesty and truth commissions, may not allow the prosecutor to select from the leaders and rank-and-file which category of the accused of the crimes under the Statute should be prosecuted by the Court and which should be left to national judicial systems. Mahnoush H. Arsanjani, The International Criminal Court and National Amnesty Laws, 93 ASIL PROC. 65 (1999).
} 
a modest form of cooperation covered by Articles 15 and 18 of the Relationship Agreement between the United Nations and the ICC. ${ }^{57}$ But a full-fledged criminal investigation-gathering testimony, collecting and securing evidence, and finally apprehending alleged perpetrators of crimes-demands much greater involvement, encompassing coordination between investigators, forensic experts, other specialists, and, of course, the local population. Most, if not all, of these activities will also require the support of police or security forces. For example, taking testimony in an ongoing conflict may entail providing witness protection locally or elsewhere and giving assurances of, or creating, an environment in which witnesses will not be subject to retaliation from the perpetrators of the crimes or their supporters. These activities require a major commitment of time and resources and, in many situations, will depend on the active cooperation and support of $\mathrm{UN}$ forces.

It would be difficult to argue that these types of cooperation are already covered by either the Relationship Agreement or the general language in most Security Council resolutions. Lawyers can always invent arguments, but it would go beyond the pale of plausibility to pretend that an interpretation in extenso of the Relationship Agreement or a Security Council resolution is a simple, permissible option. An extensive construction could radically change the nature of the mission and ignite a chain of easily imaginable consequences for the United Nations, so serious that one could not fairly assume that these obligations had been undertaken implicitly. One example: active support of ICC investigators by UN forces might create the impression in the eyes of the local population or the parties to the conflict that the investigation was a UN operation. But in many situations UN forces strive to remain scrupulously neutral in order to retain the trust of all segments of the local population. That trust would be lost and the UN forces might find themselves in a much more complicated and politically violent situation if they were perceived as part of the operation that was gathering evidence against one or another party to the conflict. A further practical problem could be possible confusion in the line of command; whom do security forces take orders from once they are called upon to provide active assistance and protection to the investigators on the ground?

In short, UN cooperation with the ICC may be expected to import new challenges for UN missions, especially when the cooperation puts the UN forces in the field into opposition to one of the contending parties that the United Nations was trying to separate. Cooperation could also import unanticipated problems for the ICC. Dependence by the Court on UN forces authorized by the Security Council in a particular situation would require it to pay more attention to what the Security Council was doing or intending to do in a particular crisis. Indeed, the Council could be in charge and could insist that the Court adjust its program so as not to "rock the boat."

The prosecutor seemed sensitive to his dependency on the Security Council in his initiative in Ituri. In a press release in July 2003 regarding the decision to investigate the situation there, the prosecutor explained, in rather detailed fashion, that his office was aware of the steps being taken by the Security Council, that it supported the efforts being made by national and international actors to help the country achieve peace, and that it would "bear these efforts in mind as it continues to follow the situation in the Democratic Republic of Congo closely." 58 This is a politically sensible and contextually reasonable position for any political entity whose area of operation overlaps with that of other political entities. For the ICC, it may prove to be a necessary evolution of role and mission. But it is a curious, if not anomalous, position for a court and especially a criminal court, a fortiori one whose designers sought independence from the Security Council.

\footnotetext{
${ }^{57}$ Relationship Agreement Between the United Nations and the International Criminal Court, Oct. 4, 2004, UN Doc. A/58/874 (entered into force Oct. 4, 2004).

${ }^{58}$ ICC Press Release, supra note 51.
} 
V.

In any manifold of events, an innovation in one part inevitably precipitates changes and potential problems elsewhere. In the normative sphere, the result is an adjustment in the law-inaction. So it is with the expectations of compensation for victims of serious crimes in the DRC. Victims want the perpetrators who tormented them to be punished, but they also expect to receive assistance from the Court, through the award of compensation, to repair their injuries, make good their losses, and start their lives anew. Thus, the DRC representative to the Sixth Committee of the UN General Assembly, in a statement regarding the ICC, observed that " $[\mathrm{t}]$ here was keen interest among the victims in the possibility that the Court could order reparations." 59

The importance of reparations for victims in settling the whole range of problems associated with the reconciliation process in postconflict situations was emphasized in the Report of the Secretary-General on the Rule of Law and Transitional Justice in Conflict and Post-Conflict Societies. The report recognized that while nonmaterial forms of reparation are easier to provide, material forms may present the "greatest challenges":

Difficult questions include who is included among the victims to be compensated, how much compensation is to be awarded, what kinds of harm are to be covered, how harm is to be quantified, how different kinds of harm are to be compared and compensated and how compensation is to be distributed.

... No single form of reparation is likely to be satisfactory to victims. Instead, appropriately conceived combinations of reparation measures will usually be required, as a complement to the proceedings of criminal tribunals and truth commissions. Whatever mode of transitional justice is adopted and however reparations programmes are conceived to accompany them, both the demands of justice and the dictates of peace require that something be done to compensate victims. Indeed, the judges of the tribunals for Yugoslavia and Rwanda have themselves recognized this and have suggested that the United Nations consider creating a special mechanism for reparations that would function alongside the tribunals. ${ }^{60}$

During the negotiation of the Rome Statute, advocates for victims pressed for more recognition of victims' needs by making provision for their support, including by the awarding of compensation. The result of their efforts was Article 79, which provides for the establishment of a trust fund for the benefit of victims of crimes within the jurisdiction of the Court, as well as for the families of victims of such crimes.

Whence comes the money for the trust fund? Article 79(2) of the Statute provides that " $[t]$ he Court may order money and other property collected through fines or forfeiture to be transferred, by order of the Court, to the Trust Fund." The novel idea of the Court's imposing fines or securing and transferring forfeited property to the trust fund seems reasonable and fair, but it may often prove impracticable. It is not at all clear that perpetrators of serious crimes accumulate substantial property or that the violence and number of atrocities correlate with the accumulation of wealth by the perpetrators. And even if a great stash of booty is stored somewhere, how can the Court secure it?

A more likely source of revenue for the trust fund is voluntary contributions by governments and private entities. Indeed, the Board of Directors of the Trust Fund for Victims, whose members are responsible for encouraging generous contributions to the trust fund by governments and private entities, is heavily endowed with high-profile personalities, ${ }^{61}$ suggesting that the states parties to the Rome Statute had no illusions about practical fund-raising. But in a world of increasing donor fatigue, can one realistically expect voluntary contributions sufficient to

\footnotetext{
${ }^{59}$ Statement of DRC delegate, supra note 52, para. 15.

${ }^{60}$ Report of the Secretary-General, The Rule of Law and Transitional Justice in Conflict and Post-Conflict Societies, UN Doc. S/2004/616*, paras. 54-55.

${ }^{61}$ The members of the Board of Directors are Queen Rania Al-Abdulah, Dr. Oscar Arias Sánchez, Mr. Tadeusz Mazowiecki, Mme. Simone Veil, and Archbishop Emeritus Desmond Tutu. The members of the board are elected by the Assembly of States Parties to the Rome Statute for a term of three years and will serve in an individual capacity on a pro bono basis.
} 
satisfy the tens of thousands, if not more, of victims of such crimes and their families? The lawin-action may scale back the scope and ambition of the trust fund, but Article 79 has already created expectations among the victims and their advocates; failure to fulfill them may affect the image of the Court.

\section{VI.}

The above considerations bring us to the "bottom line": the financial base of the ICC, the effect that resource scarcity may have on the scope of its operations and the priority that the international political system is prepared to accord to criminal justice in the maintenance of peace and security.

International criminal tribunals are proving to be immensely expensive. In his report, the UN secretary-general noted that the ad hoc tribunals for the former Yugoslavia and Rwanda, which were established at considerable cost, have expanded into large institutions, with more than two thousand positions altogether and "a combined annual budget exceeding a quarter of a billion dollars-equivalent to more than 15 per cent of the [UN] Organization's total regular budget." ${ }^{\prime 2}$ Some advocates of international criminal justice appear inclined to minimize or even dismiss the significance of these figures by comparing the costs of these tribunals to the military budgets of major powers. But the comparison is inapt, for the tribunals are not only no replacement for military defense, but, as we have seen, in the most urgent cases they may have to rely on some parts of the military apparatus. In any event, the allocations of national budgets are determined by national priorities, a reality that cannot be ignored in projecting the resources that will actually be available for the ICC.

While recognizing that the complexity of criminal trials and the impact of these tribunals cannot be measured solely in economic terms, the secretary-general's report pointedly observed that "the stark differential between cost and number of cases processed does raise important questions." ${ }^{.3}$ The report concludes that, partly in reaction to the high cost of the two ad hoc tribunals, the later mixed tribunals for Sierra Leone and for Cambodia have been financed entirely on the basis of voluntary contributions, a method that is hardly desirable-or reliable. As the secretary-general observed:

While for the Extraordinary Chambers [for Cambodia] the viability of this mechanism is yet to be tested, in the case of the Special Court for Sierra Leone, my doubts about the sustainability and security of the court's operations being financed through voluntary contributions have been borne out. Less than two years into its operation, and at the very moment when trials were about to begin, the Court has confronted a serious financial crisis. ${ }^{64}$

In addition, a world of finite resources already experiencing competition for funds for developing countries for general development, and to combat hunger, HIV/AIDS, and other human catastrophes, will have to establish international priorities. Despite the passionate conviction of many of the Court's supporters, there is no assurance that the ICC will rank high in this tragic struggle.

Serious shortcomings are becoming apparent in the regimes for financing the ICC and other international criminal law initiatives. With the Rome Statute now in operation, the Court and the states parties must confront financing problems that heretofore were theoretical. None of the obvious choices are attractive.

VII.

Compared to the expectations they generated, the achievements of recent international and hybrid criminal tribunals have been measured. These various tribunals, which were mostly of the ex post variety, have assisted in bringing some criminals to justice, promoted the development

\footnotetext{
${ }^{62}$ Report of the Secretary-General, supra note 60, para. 42.

${ }^{63} \mathrm{Id}$.

${ }^{64} I d$., para. 43 .
} 
and acceptability of both substantive and procedural international criminal law, and at least sustained, if not reinforced, the general international notion of the unacceptability of serious violations of human rights. But there is, alas, scant evidence that they have deterred such acts. Nor do the available indicators suggest that the tribunals have contributed adequately to building a sustainable national capacity for the administration of justice in precisely those states that are likely to be the crucibles for the crimes for which the Statute was created. ${ }^{65}$

The challenges facing the ICC are far greater than those its predecessors encountered, not least because, unlike its predecessors, it is an ex ante tribunal. But having embarked on this venture and generated such high expectations, the ICC, if it fails, will engender severe, indeed intolerable, costs, not simply for the ICC as an institution, but for the larger objectives of international criminal law. So, a great deal is riding on how the ICC's law-in-action is being shaped in a process that commenced, as it had to, the moment the words of the Statute were sealed in Rome. It is now up to the prosecutor, the judges of the Court, and the Assembly of States Parties to the Rome Statute, all of whom have been charged by the Statute to shape its future, to take the wise choices, within the limits imposed by the realities of international politics, that will enable the ICC to make its optimal contribution to world order and human dignity.

And perhaps there is a larger lesson, not for the lawyers who must now apply the law in the books, but to the lawyers who create the law in the books, to whom Dean Pound directed a stillpertinent admonition:

It is the work of lawyers to make the law in action conform to the law in the books, not by futile thunderings against popular lawlessness, nor eloquent exhortations to obedience of the written law, but by making the law in the books such that the law in action can conform to it ... ${ }^{66}$

THE LORD'S RESISTANCE ARMY CASE: UGANDA'S SUBMISSION OF THE FIRST STATE REFERRAL TO THE INTERNATIONAL CRIMINAL COURT

\section{By Payam Akhavan *}

On December 16, 2003, Uganda referred the situation concerning the Lord's Resistance Army (LRA) to the prosecutor of the International Criminal Court (ICC). ${ }^{1}$ It was the first time that a state party had invoked Articles 13(a) and 14 of the Rome Statute ${ }^{2}$ in order to vest the Court with jurisdiction.

${ }^{65}$ In his report, supra note 60 , the secretary-general observed:

The location of the Yugoslavia and Rwanda tribunals outside the countries where the crimes were committed has allowed them to benefit from more adequate operational facilities and has helped protect their security and independence. However,... there are a number of important benefits to locating tribunals inside the countries concerned, including easier interaction with the local population, closer proximity to the evidence and witnesses and being more accessible to victims. Such accessibility allows victims and their families to witness the processes in which their former tormentors are brought to account. National location also enhances the national capacity-building contribution of the ad hoc tribunals, allowing them to bequeath their physical infrastructure (including buildings, equipment and furniture) to national justice systems, and to build the skills of national justice personnel. In the nationally located tribunals, international personnel work side by side with their national counterparts and on-the-job training can be provided to national lawyers, officials and staff.

Id., para. 44.

${ }^{66}$ Pound, supra note 5, at 36.

- Senior Fellow, Yale Law School and Yale University Genocide Studies Program; formerly Legal Advisor, Prosecutor's Office, ICTY-ICTR. The author advised the government of Uganda in this matter. The views expressed here are those of the author in his personal capacity. The research assistance of Edgar Chen is gratefully acknowledged.

' ICC Press Release, President of Uganda Refers Situation Concerning the Lord's Resistance Army (LRA) to the ICC (Jan. 29, 2004) [hereinafter President's referral to ICC]. ICC materials, including the Rome Statute (corrected as of January 16,2002), press releases, and information on cases and situations, are available online at the Court's Web site, <http://www.icc-cpi.int>.

${ }^{2}$ July 17, 1998, UN Doc. A/CONF.183/9*, 37 ILM 999 (1998). 